\title{
The lost joys of a carefree life or are contemporary Swedish authors "banning" happiness? Interview with Francesca Dal Negro, Feltrinelli Kids editor, Italy
}

\author{
"But I will look for Lindgren's heritage also in other countries - for \\ example, Australia, New Zealand and India-because I think we \\ shouldn't 'ban' carefree happiness, goodness, and optimism from \\ children's literature". Francesca Dal Negro, Feltrinelli Kids editor, \\ Italy, about Swedish contemporary literature.
}

The first thing that came to my mind in connection with the words "censorship" and "Swedish children's literature" was the debate a few books by contemporary Swedish authors recently started in Italy.

For several years, Italian publishing houses favoured politically correct children's stories with a strong educational content. This tradition was interrupted when Astrid Lindgren's books were first published in Italy, causing havoc among children's educators for their controversial and independent main characters. But, in more recent years, a new generation of Swedish writers stirred new controversy in the country. Parents, teachers, academics, librarians and booksellers often wondered if it was appropriate for an 8 year-old child to read Per Olof Enquist's De tre grottornas berg (Italian title: La montagna delle tre grotte), that boasts, among its main characters, an unconventional grandfather who tells jokes about farts and poo, or Ulf Stark's Dårfinkar och dönickar (Italian title: Il paradiso dei matti), a short novel that explores the discovery of sex and sexuality and even features a young boy's first erection (probably the first erection to be described in a children's book ever published in Italy).

Throughout February and March 2008 I embarked on what I would describe as a "research adventure" in the world of children's books written by Swedish authors and published in Italy that were somehow deemed as scandalous. I spoke to parents and educators, children and passionate readers from the North, Centre and South of Italy, basing my analysis on three books: Per Olof Enquist's De 
tre grottornas berg, Ulf Stark's Dårfinkar och dönickar and Ylva Karlsson's Josefin (Italian title: Nessuno mi parla con voce di miele). The books were selected after a private consultation I carried out with two parents (a father and a mother), a teacher, a librarian and a bookshop owner in Pescara, Italy, in January 2008. Enquist's book was chosen for the language used by the grandfather; Karlsson's for her portrayal of a modern family; Stark's for how it treats contemporary issues of concern to youth, among them insecurity and sexuality.

My analysis confirmed my doubts: the sixty 8-9-year old children interviewed through written questionnaires and group discussions, weren't scandalised by the language used in the three books they had read, nor did they think the books were particularly controversial because of their contents. Children sympathised with the main characters in the books, they indeed felt the stories had somehow liberated them, providing them with an opportunity for catharsis and self-knowledge. Some children even claimed that, at some point in their lives, they had experienced what happened to at least one of the characters in the three stories or that the virtues - such as courage - found in the books, helped them dealing with their emotions and fears. All of them stated they liked the language used in the three novels, explaining how the authors had managed to describe children's thoughts and frustrations while also succeeding in grasping the language used by children nowadays.

The adults interviewed -60 in total - were divided in two groups: 35 to 45 years old and 45 to 65 years old. This survey was mainly carried out through group interviews and debates. The two groups (30 +30 ) were divided in two sub-groups of 15 people each. Each book was discussed with 15 different people in 1 hour / 1 hour and 30 minute sessions. The majority of the 35 to 45-year-old group agreed with the interviewed children, but an internal division split the second group in various sub-groups with grandparents that found the language somehow embarrassing, parents who thought the contents were in part inappropriate and teachers who found both the language and the content unsuitable. 
My investigation also allowed me to exchange a few ideas and thoughts with two literary agents and one marketing expert, all of them Italian, who explained how they sometimes found it difficult to convince a publishing house to buy a particular book by a Swedish author because of its main themes. Their feedback inspired me to contact Francesca Dal Negro, Editor at Feltrinelli Kids (imprint of the Italian Feltrinelli publishing house) and discuss with her the problem of censorship and Swedish books for children in Italy. Francesca Dal Negro has worked in the publishing business since 1991. In 2000, after collaborating with RCS Libri and working as editor of the Delfini Bompiani imprint, she moved with the Milan-based Feltrinelli publishing house. She became editor of the Feltrinelli Kids imprint in 2007.

During the last few years Feltrinelli Kids has published more books by Swedish authors - among them Per Olof Enquist, Inger Lindahl, Ulf Stark and Annika Thor - than any other Italian publishing house. This Sweden-oriented editorial line was put forward by Valeria Raimondi, the imprint's previous editor. The books by Swedish authors included in the Feltrinelli Kids catalogue proved rather popular, showing no sign of decline among children and young readers and turning out as one of the most popular and finest literary imports on the Italian market. When at the end of 2007 the new editor Francesca Dal Negro arrived at Feltrinelli Kids, she began to question Raimondi's editorial choices. All the previously published Swedish books were valid, beautifully written and touched upon contemporary issues that are very relevant to today's children. Yet, according to Dal Negro, something was missing in these titles: it was as if Swedish contemporary authors had "banned" from their books the realm of fantasy and those wonderful, carefree and fantastic adventures that characterised Astrid Lindgren's stories. Many questions riddled her mind: why were fantastic themes missing and should some of the Swedish authors concentrating on more "serious" themes be "banned" from the publishing house catalogue to give more space to different kind of books, maybe titles that allowed children to dream again about fantastic worlds, perfect friendships and unrivalled freedom?

Dal Negro's criticism was interesting but it focused in part on an evaluative stance based on a personal perspective, oriented to constructing a parallel between the works of contemporary Swedish authors and Astrid Lindgren's stories. New questions arose in my mind during and after my interview: was Dal Negro trying to find the "elusive" perfect book for children while representing childhood 
as a surer, safer and happier universe, as adults often perceive it is? Did her perception of contemporary Swedish authors reflect the rich variety and complexity of contemporary Scandinavian literature and of modern children's tastes or her own tastes? Dal Negro's feedback inspired me to shift the focus of my essay and present her point of view in form of an interview. Hopefully, her answers will open a new debate on contemporary Swedish literature for children, but will also inspire Italian and Swedish authors to ponder on their readers' needs and generate a new approach in the publishers' ongoing search for the "perfect book" for children and young readers.

\section{Interview with Francesca Dal Negro, Feltrinelli Kids Editor, $16^{\text {th }}$ April 2008:}

What did your critical approach to contemporary Swedish authors for children reveal you?

When I started working for the Feltrinelli Kids imprint I realised we had many contemporary authors in our catalogue. We definitely had a good portfolio - some authors had already been published, others had yet to be translated - but all of them were really excellent writers. What happened, though, is that I started reading contemporary Swedish authors hoping to find in at least some of them Astrid Lindgren's heritage, that is a fantastic world made of freedom, independence and happiness, though Lindgren also tackled existential problems through myth and fairy tale in Mio, Min Mio (Italian title: Mio Piccolo Mio), used an adventure story as an allegory on life and death in Bröderna Lejonhjärta (Italian title: I fratelli Cuordileone), and explored through the fantasy-oriented novel Ronja Rövardotter (Italian title: Ronja, la figlia del brigante) the good/evil and peace/violence dichotomies. For decades Lindgren's stories helped developing Italian children's literature, but reading these new authors brought a new discovery for me: Lindgren's universe and her belief in the brighter side of life doesn't seem to exist anymore in contemporary Swedish children's literature. Sweden still produces extraordinary authors, but the world they describe seems to me brutally real. We recently published Annika Thor's Sanning eller konsekvens (Italian title: Obbligo o verità?) and Inger Lindahl's Priset (Italian title: L'inverno non è per sempre) and, in 2009, we will publish Katarina Mazetti's Det är slut mellan Gud och mig. I do think these are magnificent authors as they manage to describe everyday life and issues such as bullying, alcoholism and suicide in an amazing way. Italian authors don't seem to 
have the words or the skills to tackle the same issues as effortlessly as Swedish authors do, or maybe Italian authors censor themselves when they opt not to write about such themes. Yet there is something missing in contemporary Swedish stories and that's the carefree attitude and freedom experienced by Lindgren's characters. Laughter, for example, is not exactly an ever-present feature of contemporary Swedish children's literature, while sadness and melancholy are often there. The society described by these Swedish authors is a society in which children and teenagers have many problems - which are maybe the same problems of their Italian counterparts - but I don't think that a good writer should always tell a story from a realistic point of view. I think that children's stories must appeal to the imagination and they shouldn't be sociological pamphlets. Take J.K. Rowling: she brought her hero from childhood to adulthood in the Harry Potter saga writing about a fantastic world where magicians challenged each other and she succeeded rather well in her attempt. Rowling's series has its origin in myths, fairy tales and folklore, but it's still utterly original. Besides, she managed to do something unique: the Harry Potter stories are somehow multi-layered and some of their layers - such as the allegoric ones - can only be seen by adult readers, so, thanks to their simultaneous simplicity and complexity, the books appeal to both children and adults. While looking for the answer to all my questions about why the main themes of contemporary Swedish stories changed so much in the last few years, I realised that maybe these authors simply decided to ban from their stories those sheer and joyous escapes that characterised many Lindgren's stories.

\section{What do you think about the language used by Swedish authors in their books?}

I read all the Swedish authors Feltrinelli Kids published so far through Laura Cangemi's impeccable translations into Italian. I think that these authors always manage to say what they feel, and usually develop a serious theme in an entertaining way, finding the proper words to tell their stories. I never spotted any vulgarities while reading one of the stories we published. These authors manage to clearly describe situations that are often deemed as scandalous without wanting to sound revolutionary as American authors tend to do. Swedish writers seem to have a perfectly untroubled relationship with sex or death, themes that we often consider as taboos in Italy or as more suitable for grown-ups. Yet I think the price they pay is banning from their stories light-hearted and cheerful themes, that infancy inebriated with freedom that the kids from Vi på Saltkråkan (Italian title: Vacanze all'isola dei gabbiani) lived is for example missing from some 
of the stories we published years ago. This is basically what made me consider that it's fair enough to tackle everyday problems and issues, but maybe we should also try to bring back more exciting and fantastic universes in literature. I sometimes get the feeling that realism to some writers is only the harsher side of life, while literature means to understand, create and experience not only the world around us, but also the domain of our dreams and desires. A fantasy tale can do so much for children, as it can expand horizons and instil in its readers a sense of the wonderful complexity of life.

While visiting Italian schools, did you ever meet any children who critically analysed with their teachers any Swedish books published by Feltrinelli Kids?

Annika Thor's book was nominated for the 2007 Paolo Ungari Award and it was included in a list of books that a few selected Italian schools analysed. At the final ceremony of the Ungari Awards at the Rome Auditorium the authors met the schoolchildren who had read their books and it was on this occasion that I realised the potential of Thor's novel and how a book about an intelligent topic could work very well, especially in the school environment. It was there that I discovered the interaction children could have with these books and how the implied child readers had created a relationship with the author by personalising the story in the book and revealing how bullying is quite a pervasive phenomenon among children, probably to a greater extent than most teachers and parents realise, since many victims keep quiet about it. The debate that followed between the authors and the children wasn't banal at all, as children wanted to talk about their personal experiences and share them with the authors. Children proved they were active readers, aware of the contents and implications of the story. If a successful book is seen from the way it draws children into the text, then Thor's novel is undoubtedly a successful book. Yet it must be highlighted that the novel hadn't been read in its integrity, but a sort of "censorship" had been applied as teachers selected particular bits out of the story thinking that other parts were too dark for primary school children.

What's your editorial choice for the future: should those Swedish authors tackling more "serious" issues be "banned" from the publishing house catalogue or will the imprint keep on publishing them?

Throughout the last months I often wondered what to do, if I should go where my heart takes me or if I should follow the previous edi- 
torial line. I think the way forward is to balance these two things. It wouldn't be right for me to say 'I don't want a hard-hitting story from Sweden dealing with a painful and difficult subject' as the Swedish authors we published contributed to give quality and credibility to our catalogue and proved educationally, socially and commercially important. But I will look for Lindgren's heritage also in other countries - for example, Australia, New Zealand and India - because I think we shouldn't "ban" carefree happiness, goodness and optimism from children's literature, we shouldn't suffocate it with everyday problems. I think this is a point of vital importance as captivating stories that weave fantasy and reality together can help children all the same to face everyday problems while they can also encourage them to read more. I think the lesson that the unpredictable and unexpected universal success of Harry Potter gave us is very important: when it was published in Italy, Robert L. Stine's Goosebumps (Italian title: Piccoli Brividi) book series was very popular and most of our editors didn't have any faith in Rowling's magic world, yet her book ended up in being phenomenally successful, as it satisfied the readers' thirst for a great and beautiful saga while also giving children a hero to grow up with. This said, I don't think the real problem is censoring or not censoring a book, banning or not banning a title from our catalogue, but it's more about wondering which values we are bringing to our readers with the books we publish. I hope that children's authors, too, will ask themselves the same question.

\section{Bibliography}

Enquist, Per Olof. La montagna delle tre grotte, transl. by Laura Cangemi (Original title: De tre grottornas berg). Milan: Feltrinelli Kids, 2004.

Karlsson, Ylva. Nessuno mi parla con voce di miele, transl. by Laura Cangemi (Original title: Josefin). Milan: Salani, 2003.

Lindahl, Inger. L'inverno non è per sempre, transl. by Laura Cangemi (Original title: Priset). Milan: Feltrinelli Kids, 2008.

Stark, Ulf. Il paradiso dei matti, transl. by Laura Cangemi (Original title:

Dårfinkar och dönickar). Milan: Feltrinelli Kids, 2004.

Thor, Annika. Obbligo o verità?, transl. by Laura Cangemi (Original title: Sanning eller konsekvens). Milan: Feltrinelli Kids, 2007.

Interview with Francesca Dal Negro, Feltrinelli Kids Editor, 16 ${ }^{\text {th }}$ April 2008.

Nyckelord: Svensk barnlitteratur Italien, censur, urvalskriterier 